\title{
Assessment of educational experiences on professional nursing practice
}

\author{
Ryan Ray G. Gatbonton \\ Chinese General Hospital Colleges, Philippines
}

Correspondence: Ryan Ray G. Gatbonton, Chinese General Hospital Colleges, Manila, Philippines, Email: ryan.gatbonton@gmail.com

Received: October 15, 20I8 | Published: November 12, 2018

Copyright@ 2018 Gatbonton. This is an open access article distributed under the terms of the Creative Commons Attribution License, which permits unrestricted use, distribution, and reproduction in any medium, provided the original author and source are credited.

\begin{abstract}
Purpose of the Study

Alignment of educational program implementation to professional practice is an important responsibility of every higher education institution. This study aimed to evaluate the experiences of alumni on the nursing education they have received and correlate it to their respective practice.

\section{Methodology}

Underpinned on the pragmatic concept of education, 112 graduates of a nursing college in Manila, Philippines, selected through quota sampling, were surveyed using a national tracer study questionnaire developed by the Commission on Higher Education. The experience they had on instructional methodologies was correlated to their respective practice of the nursing profession.

\section{Results and Discussions}

Findings of the survey revealed that the respondents had perceived excellence on their alma mater's curriculum of degree program $(\bar{x}=4.37)$, grading system $(\bar{x}=4.26)$, quality of instruction $(\bar{x}=4.26)$, provision of faculty consultation $(\bar{x}=3.79)$, supply of teaching materials $(\bar{x}=3.97)$, library collection and facilities $(\bar{x}=3.88)$, emphasis on research $(\bar{x}=3.79)$, extra-curricular activities $(\bar{x}=3.77)$ and availability of work-related experiences $(\bar{x}=$
\end{abstract}

\section{Introduction}

Program relevance is an important aspect that every higher education institution must pay attention to. Ensuring its significance to professional practice assures that graduates are prepared and capable to handle work-related situations. Appropriate attitudes expected of a professional can be observed from these graduates as they enter the workplace. Moreover, graduates can be easily assimilated to their respective industries as long as their instructional program is connected to the requirements of the profession. Thus, it is important to assess the educational experience of the alumni in the college and analyze its impact to their respective practices.

Studies have shown a strong link between relevance of education in the development of nations through attainment of a strong moral sense through sharpened cognitive ability and increased competence ${ }^{1}$ and innovative work attitudes and skills ${ }^{2}$. These factors are known to be determinants of good economic outcomes both at the personal level and at the national level ${ }^{4,5}$. The role of the school in developing the abilities of its graduates has been seen as the most important factor to uplift a student's intelligence. ${ }^{6-8}$ These research evidences therefore imply the significance of instruction of schools should be aligned well to national interest, agenda and industry needs.
4.30). Participants, on average, were satisfied with the computer and internet facilities $(\bar{x}=3.47)$, technical equipment $(\bar{x}=3.71)$, participation in research projects $(\bar{x}=3.79)$, community extension activities $(\bar{x}=3.63)$, availability of scholarships $(\bar{x}=3.55)$ and participation in school policy formulation $(\bar{x}=$ $3.53)$. The college's approach in education were highly relevant in terms of job placement $(\bar{x}=4.22)$, long-term career prospects $(\bar{x}=4.12)$ and personality development $(\bar{x}=4.26)$. No difference in the educational experience was perceived by the alumni through the years $(p=0.06)$ and among males and females $(p=0.32$ ). There was significant positive relationship between overall instructional experience to job placement $(p<0.01)$, long-term career prospects $(p<0.01)$ and personality development $(p<0.01)$.

\section{Conclusion}

Consistent with the tenets of pragmatic education, the actual instructional experiences of the alumni significantly translate into their professional nursing practice. These findings present implications to leaders of higher education institutions in devising means to improve integration of industry needs into teaching implementation strategies and policies.

Keywords: nursing education, curriculum implementation, curriculum evaluation, education administration

Education is the sum total of the instruction, experiences and policies that are promulgated to effect learning to the students. Several academic researches assert that the quality of education is achieved by the interplay of different factors. Curriculum plays an important role in the sequencing and introduction of concepts to be learned by the students. Knowledge, skills, attitude and values are ensured to be transferred through the implementation of the five concurrent curricula - the official, operational, hidden, null and extra curricula. ${ }^{9}$ The curriculum needs to be the practical basis of every education offering programs of study. ${ }^{10}$ Formative and summative evaluation are also important to gauge the development of learning among students. It does not only promote monitoring of student progress, it also improves the very outcome of education itself. ${ }^{11}$ Mayworm and colleagues ${ }^{12}$ have discovered that teacher consultation is key to ensuring restorative justice to students who misbehave in school. They asserted that teachers need to adopt restorative justice approaches to improve their teaching strategies and learning outcomes. Likewise, the kind of instruction, adequacy of educational resources, presence of co- and extracurricular activities, participation in community extension the students actually experience determine how the students translate their learning into responsible and meaningful practice. ${ }^{13-17}$ Scholarship and school policy concerns also improves 
educational outcome if it is streamlined with inputs from the academic community. ${ }^{18}$ These factors are considered to be essential to ensure a responsive and relevant education for everyone.

In the Philippines, the issue of jobs-to-skills mismatch continues to affect its unemployment rates. Data from the Department of Labor and Employment in 2016 reveal that an average of 30\% of job applicants was hired on the spot in a job fair that the government agency has conducted. These findings highlight a possible mismatch between the knowledge and skills of graduates and the demands of the labor market. This reality affects both the individual's and the nation's economic progress. Therefore, it becomes a necessity that the instructional practices of academic institutions be tweaked according to the needs of different professions, in particular, and the nation, in general.

In line with these concerns, this research assessed, compared and correlated the perception of the alumni of a nursing program on their experience on the services of the institution and its relevance to their workplace environment. It is the hope of this study to seek areas of improvement and as well as validate the relevance and effectiveness of its instructional program.

\section{Methodology}

The study utilized correlation and comparative research designs that explored various aspects of the graduates' experiences from college life and correlated it to professional practice. The variables that were explored are educational attainment, job application methods, employment status of respondents, nature of business of their current employers, instructional methodologies of the College and its implications to professional and personal growth.

The target population of the study was the intuition's higher education nursing program graduates. The college offering the nursing program can be described as an institution of higher learning that envisions its graduates as a holistic and humane nurse professional and is wellrounded. A quota sample of $10 \%$ of the total graduates from 2007 to 2012 was determined. This sample size estimation was used because large effect size was anticipated from the group; and that the respondents' characteristics are considered to be homogenous in terms of the education they have received from the institution of higher learning. Response and attrition rates are summarized in Table 1.

Table I Response and attrition rates

\begin{tabular}{lll}
\hline & $\boldsymbol{n}$ & $\mathbf{( \% )}$ \\
\hline Response Rate & 112 & $78.87 \%$ \\
Attrition Rate & 30 & $21.13 \%$ \\
\hline Total & 142 & $100.00 \%$
\end{tabular}

The graduate tracer study questionnaire, which was adopted from a tool utilized by a national graduate tracer study, authored by the Philippine Commission on Higher Education, was used to assess the respondents' professional/educational status and experience after college graduation. The modified tool is composed of seven parts: personal information part, assessment of highest educational attainment, method of job acquisition, type of the graduates' employment, employment information, evaluation of collegiate services and relevance of education to current employment. The part on evaluation of collegiate service is composed of 15-items which assessed satisfaction of graduates in terms of curriculum, grading system, instruction, teaching materials, consultation hours, research/ community extension activities, scholarships, work placement and co-/extra-curricular activities. Three items were used to assess the relevance of education to current employment. Effectiveness and real-life appropriateness of the BSN program's instructional methods were measured using a five-point scale (5 - Very Satisfactory, 4 Satisfactory, 3 -Average, 2 - Dissatisfactory, 1 - Very Dissatisfactory). Content and construct validity was assured as this tool was developed and promulgated by panel of experts in national higher education. Internal consistency was measure, and the tool was deemed highly reliable and consistent (Cronbach's $\bar{x}=0.96$ ).

Upon approval of the research committee on ethics of the higher education institution of study, an online version of the questionnaire was published through Google Forms. Information about the graduate tracer study was disseminated through social networking sites. The online form was opened and was asked to be filled out with prospective respondents. All data were automatically transcribed into a spreadsheet generated by Google Drive.

Mean and standard deviation were used to summarize the data. Independent t-test was used to determine difference in perceived satisfaction between male and female alumni. One-way analysis of variance was used to determine differences in perceived satisfaction among alumni from different batches. Pearson product-moment correlation coefficient was used to determine the association between the satisfaction on school services to its perceived relevance. SPSS version 18 was utilized to manage data and perform statistical treatment.

All respondents were informed about the purpose, benefits and risks of the study which were indicated in the online/printed questionnaire. They were given the right not to join the study. Informed consent was signified through the voluntary accomplishment of the survey. The researcher has the sole access to the responses gathered. Results of the study were used only for institutional/instructional planning and research purposes and reported in the aggregate so that identifiers were removed from individual data.

Frequencies and percentages were used to summarize the demographic and professional characteristics of the respondents. The mean of the scales used in the questionnaire were determined. Results are interpreted according to Table 2.

Table 2 Rating system

\begin{tabular}{ll}
\hline Score Range & Interpretation \\
\hline $\mathbf{1 . 0 0}-\mathbf{2 . 2 5}$ & Poor \\
$\mathbf{2 . 2 6}-\mathbf{3 . 7 5}$ & Average \\
\hline $\mathbf{3 . 7 6}-\mathbf{5 . 0 0}$ & Excellent \\
\hline
\end{tabular}

\section{Results and Discussions}

This section contains the summary of responses gathered from the participants of the graduate tracer study.

Table 3 describes the demographic profile of the respondents. The data shows that majority of those who participated in the study are female $(n=79 ; 70.54 \%)$. It was also shown that most of the respondents are situated in the Philippines $(n=90 ; 80.36 \%)$. The inclusion criteria could have an impact to this result because they may still be gathering the work experience needed to be employed overseas. The primary industry where graduates of nursing program were placed is in the 
healthcare industry $(n=88 ; 78.57 \%)$. This result can tell that the products of the institution are prepared for healthcare tasks. On the other hand, a considerable number of respondents have been working in other industries. This can indicate that the academic program of the institution can also equip students with skills aside from clinical setting. Different subject in liberal arts and general education were offered concurrently with the professional nursing subjects of the students. Moreover, this serves as a measure of achievement of the college's core values (i.e. capability building for life effectiveness and development of workplace relevant competencies). In terms of educational preparation, it is notable that 23 out 112 respondents $(20.54 \%)$ have pursued higher education. Since allied health professions, such as nursing, require continuous education to improve practice, this could have an influence on their decision to engage in graduate studies or continuing professional education.

Table 3 Demographic profile of respondents

\begin{tabular}{lll}
\hline Gender & $\mathbf{n}$ & $\mathbf{( \% )}$ \\
\hline Male & 33 & $29.46 \%$ \\
Female & 79 & $70.54 \%$ \\
Total & $\mathrm{I} / 2$ & $100.00 \%$ \\
Place of Residence & & \\
Local & 90 & $80.36 \%$ \\
Abroad & 22 & $19.64 \%$ \\
Total & $\mathrm{I} / 2$ & $100.00 \%$ \\
Nature of Current Employment & & \\
Advertising & $\mathrm{I}$ & $0.89 \%$ \\
Arts/Entertainment & 2 & $1.79 \%$ \\
Business Process Outsourcing & $\mathrm{I}$ & $0.89 \%$ \\
Education/Academe & 5 & $4.46 \%$ \\
Entrepreneurial & $\mathrm{I}$ & $0.89 \%$ \\
Healthcare/Clinical & 88 & $78.57 \%$ \\
Pharmaceutical & 2 & $1.79 \%$ \\
Others (Not Specified) & $\mathrm{I} 2$ & $10.71 \%$ \\
Total & $\mathrm{II}$ & $100.00 \%$ \\
Educational Attainment & $n$ & $(\%)$ \\
Bachelor's degree & 89 & $79.46 \%$ \\
Some units of master's degree & $\mathrm{II}$ & $9.82 \%$ \\
Completed master's degree & $\mathrm{I} 2$ & $10.71 \%$ \\
\hline Total & $\mathrm{II} 2$ & $100.00 \%$ \\
\hline & & \\
\hline
\end{tabular}

Table 4 shows the source of job vacancy that the graduates utilized to secure employment opportunities. The primary source of job vacancy information of the respondents' is through an advertisement $(n=23$; $20.54 \%)$. This indicates that the respondents primarily sought jobs that were made available publicly, which is similar to usual cases of job application.

Table 5 reflects the perceptions of the respondents on the different services of the college the studied in. The overall perception on the college's services is excellent $(\bar{x}=3.86)$. The aspect that received the highest perception is in the area of curriculum of degree program ( $\bar{x}=4.37$ ). The availability of the computer and internet services received the lowest satisfaction score $(\bar{x}=3.47)$. This could have been influenced by the fact that the institution is a non-profit school and is having limited resources to expand their equipment for information and communication technology.

Table 4 Source of job vacancy information

\begin{tabular}{lll}
\hline Source of Job Vacancy Information & $\boldsymbol{n}$ & (\%) \\
\hline Advertised Vacancy & 23 & $20.54 \%$ \\
Inquiry to Employers & 17 & $15.18 \%$ \\
Job-Search Sites & 7 & $6.25 \%$ \\
Contacted by Employer & 9 & $8.04 \%$ \\
Job Fairs & 4 & $3.57 \%$ \\
Referrals from College Professors/ & 14 & $12.50 \%$ \\
Administrators & 7 & $6.25 \%$ \\
Network of Colleagues & 16 & $14.29 \%$ \\
Referrals from Personal Connections/ & & \\
Contacts & $\mathrm{I}$ & $0.89 \%$ \\
Family Company or Business & $\mathrm{I}$ & $0.89 \%$ \\
Self-Employed & $\mathrm{I}$ & $0.89 \%$ \\
Continued Job as a Working Student & 12 & $10.71 \%$ \\
Others (Not Specified) & $\mathrm{II}$ & $100.00 \%$ \\
\hline Total &
\end{tabular}

Table 5 Satisfaction with college services

\begin{tabular}{|c|c|c|c|}
\hline Aspect of College Service & Mean & SD & Remarks \\
\hline Curriculum of degree program & 4.37 & 1.01 & Excellent \\
\hline Testing/grading system & 4.26 & 1.04 & Excellent \\
\hline Quality of instruction & 4.26 & 0.97 & Excellent \\
\hline $\begin{array}{l}\text { Opportunity for faculty } \\
\text { consultation beyond class } \\
\text { hours }\end{array}$ & 3.79 & 0.94 & Excellent \\
\hline Supply of teaching materials & 3.97 & 0.96 & Excellent \\
\hline Library collection and facilities & 3.88 & 1.00 & Excellent \\
\hline Computer/internet facilities & 3.47 & 1.11 & Average \\
\hline Technical equipment & 3.71 & 0.95 & Average \\
\hline Emphasis on research & 3.79 & 1.03 & Excellent \\
\hline $\begin{array}{l}\text { Participation in research } \\
\text { projects }\end{array}$ & 3.63 & 0.96 & Average \\
\hline Extra-curricular activities & 3.77 & 1.01 & Excellent \\
\hline $\begin{array}{l}\text { Opportunities for community } \\
\text { activities }\end{array}$ & 3.63 & 1.05 & Average \\
\hline Availability of scholarships & 3.55 & 1.13 & Average \\
\hline $\begin{array}{l}\text { Student participation in } \\
\text { formulation of school policies }\end{array}$ & 3.53 & 1.17 & Average \\
\hline $\begin{array}{l}\text { Provision of work-related } \\
\text { experiences (i.e. RLE) }\end{array}$ & 4.30 & 1.01 & Excellent \\
\hline Overall Rating & 3.86 & 1.03 & Excellent \\
\hline
\end{tabular}


Satisfaction with educational services is primarily anchored on the curriculum of the degree program. Curricular offerings are seen as the main ingredient in molding the teaching-learning milieu for the students because it provides students with the needed template for learning what is important. ${ }^{19}$ With this, the quality of instruction, determination of educational resources and other factors in curriculum implementation, most especially in health science education Challenges in organizational, structural, resource and experiential will have to be faced to offer quality nursing education to students. ${ }^{20}$ Furthermore, the provision of community extension activities seems to be perceived as important because it improves cognitive, affective and psychomotor learning. ${ }^{21}$ These activities introduce the students to contextual learning environments that help them operationalize the learning they had in the classroom. Likewise, a research-based curriculum works enable students to imbibe critical thinking and scientific orientation, which is needed in the conduct of the profession. ${ }^{22}$

Table 6 lists the evaluation of the respondents on the education they receive and its relevance in their respective careers. The college's instruction is perceived to be relevant in terms of personality development $(\bar{x}=4.26)$, job placement $(\bar{x}=4.22)$ and longterm career prospects $(\bar{x}=4.12)$. These findings reveal how the instructional methodologies of the college have been relevant to the respondents in respect to their own profession.

Table 6 Perceived relevance of instruction

\begin{tabular}{llll}
\hline Relevance of Instruction & Mean & SD & Remarks \\
\hline Job placement & 4.22 & 1.03 & Excellent \\
Long-term career prospects & 4.12 & 0.99 & Excellent \\
\hline Personality development & 4.26 & 0.97 & Excellent \\
\hline
\end{tabular}

Table 7 shows the comparison of perceived satisfaction on college services across batches using one-way analysis of variance. It has been statistically proven that there is significant difference in the perceived satisfaction in the areas of curriculum, faculty consultation, teaching materials, library collection, computer facilities, technical equipment, research, extracurricular activities, scholarships and provision of work-related experiences. These results may have been influenced by a change in the Philippine nursing curriculum which has an effect on how instructions were implemented. It can be implied that the changes are directed towards improvement as evidenced by consistent exemplary performance in the Nurse Licensure Examination and the number of graduates who are hired as healthcare professionals.

Table 8 shows the comparison of perceived satisfaction on college services between male and female graduates. It can be noted that there is no difference in perception in all aspects of college services except in areas of extracurricular activities, scholarships and participation in school policy formation. These equivalent perceptions only show that the college is developing their graduates equally regardless of their gender. Conversely, the non-equivalent perceptions can be affected by internal factors that have been overlooked because of the load and nature of the BS Nursing program.

Table 9 shows the correlation of perceived satisfaction on college services to relevance of instruction. Pearson correlation coefficients on each aspect show significant moderate positive relationship. These findings denote that the respondents view the instructional method and the academic preparation they receive as relevant to their professional practice in terms of getting a job, long-term career prospects and personality development. Direct and indirect implications can be derived from these: For one, the findings suggest that there is congruence of instructional method of the school to the requirements of the healthcare industry. Secondly, the abilities and morals inculcated to the graduates are perceived to be self-enabling, which means that the core values of the school are embedded into its curriculum. ${ }^{21}$ And lastly, it can be interpreted that the training program of the school allows it graduates to be hired easily in the healthcare sector. A positive correlation in the school climate, involving the factors of curriculum, instruction, research and others, is an important determinant of learning outcomes. This has been proven in several researches that measure the same construct. ${ }^{23}$ Moreover, the interplay of multiple factors were seen as the influencer of a relevant education. ${ }^{24}$ These findings tell that instructional essentials of the nursing program under study is aligned and matched with the healthcare industry needs.

Table 7 Comparison of satisfaction on college services across batches

\begin{tabular}{|c|c|c|}
\hline Aspect of College Service & $\mathbf{F}$ & Sig. \\
\hline Curriculum of degree program & 1.855 & $.04 I^{*}$ \\
\hline Testing/grading system & 1.204 & .285 \\
\hline Quality of instruction & 1.406 & .165 \\
\hline $\begin{array}{l}\text { Opportunity for faculty consultation beyond } \\
\text { class hours }\end{array}$ & 2.050 & $.022 *$ \\
\hline Supply of teaching materials & 2.083 & $.019 *$ \\
\hline Library collection and facilities & 3.004 & $.001 *$ \\
\hline Computer/internet facilities & 2.602 & $.003 *$ \\
\hline Technical equipment & 1.853 & $.042^{*}$ \\
\hline Emphasis on research & 2.183 & $.014 *$ \\
\hline Participation in research projects & 2.059 & $.021 *$ \\
\hline Extra-curricular activities & 1.928 & $.032 *$ \\
\hline Opportunities for community activities & 1.543 & .110 \\
\hline Availability of scholarships & 1.895 & $.036 *$ \\
\hline $\begin{array}{l}\text { Student participation in formulation of } \\
\text { school policies }\end{array}$ & 1.697 & .069 \\
\hline $\begin{array}{l}\text { Provision of work-related experiences (i.e. } \\
\text { RLE) }\end{array}$ & 2.341 & $.008 *$ \\
\hline
\end{tabular}

*significant at $\alpha=0.05$

Table 8 Comparison of satisfaction on college services between male and female graduates

\begin{tabular}{ll}
\hline Aspect of College Service & Sig. \\
\hline Curriculum of degree program & .696 \\
Testing/grading system & .376 \\
Quality of instruction & .756 \\
$\begin{array}{l}\text { Opportunity for faculty consultation beyond } \\
\text { class hours }\end{array}$ & .431 \\
Supply of teaching materials & .295 \\
Library collection and facilities & .518 \\
Computerlinternet facilities & .053 \\
Technical equipment & .338 \\
Emphasis on research & .413
\end{tabular}




\begin{tabular}{ll}
\hline Table Continued & \\
\hline Aspect of College Service & Sig. \\
\hline Participation in research projects & .316 \\
Extra-curricular activities & $.009 *$ \\
Opportunities for community activities & .163 \\
Availability of scholarships & $.019 *$ \\
$\begin{array}{l}\text { Student participation in formulation of } \\
\text { school policies }\end{array}$ & $.039 *$ \\
$\begin{array}{l}\text { Provision of work-related experiences (i.e. } \\
\text { RLE) }\end{array}$ & .310 \\
\hline
\end{tabular}

*significant at $\alpha=0.05$

\section{Conclusion and Recommendations}

Consistent with the tenets of pragmatic education, it can be concluded that the nursing program under study is relevant to the needs of the nursing profession. The perception of the alumni on the education they received has a positive impact on the career they are pursuing. It is recommended that the educational practices of the college should be continued with consideration to the curriculum implemented by the Commission on Higher Education and other regulating agencies. It recommended, however, that attention be given in the areas of extracurricular activities, scholarships and participation in school policy formation and research to ensure students get equal access to such services. If actions will be taken to ensure this, it can help the students to be more flexible and prepared in professional practice.

With these research findings, several suggestions can be made to the higher education institution to further align their instruction to industry needs:

1. Establish a curriculum committee/department that will serve as a liaison of the college to industry partners.

2. Involve the healthcare sector and stakeholders in the cooperative development and implementation of the curriculum.

3. Provide detailed information about the school's training capabilities to all of its industry partners.

4. Require the professors to engage back in the healthcare industry through clinical practice or expertise sharing.

5. Develop a faculty development program that embeds current healthcare practices and work-related values.

6. Forge partnerships with healthcare institutions to bolster their inservice training of medical staffs.

7. Tap the aid of the government agencies in funding the school's development initiatives related to curriculum and instruction.

Table 9 Correlation of satisfaction on college services and perceived relevance of instruction

\begin{tabular}{|c|c|c|c|c|}
\hline & & Getting a job & $\begin{array}{l}\text { Long-term career } \\
\text { prospects }\end{array}$ & $\begin{array}{l}\text { Personality } \\
\text { development }\end{array}$ \\
\hline \multirow{2}{*}{ Curriculum of degree program } & Pearson $(r)$ & $.647^{*}$ & $.682^{*}$ & $.648^{*}$ \\
\hline & Sig. (2-tailed) & .000 & .000 & .000 \\
\hline \multirow{2}{*}{ Testing/grading system } & Pearson $(r)$ & $.604^{*}$ & $.635^{*}$ & $.625^{*}$ \\
\hline & Sig. (2-tailed) & .000 & .000 & .000 \\
\hline \multirow{2}{*}{ Quality of instruction } & Pearson $(r)$ & $.631^{*}$ & $.664^{*}$ & $.642^{*}$ \\
\hline & Sig. (2-tailed) & .000 & .000 & .000 \\
\hline \multirow{2}{*}{$\begin{array}{l}\text { Faculty consultation beyond } \\
\text { class hours }\end{array}$} & Pearson $(r)$ & $.601^{*}$ & $.606^{*}$ & $.591^{*}$ \\
\hline & Sig. (2-tailed) & .000 & .000 & .000 \\
\hline \multirow{2}{*}{ Supply of teaching materials } & Pearson $(r)$ & $.652^{*}$ & $.653^{*}$ & $.666^{*}$ \\
\hline & Sig. (2-tailed) & .000 & .000 & .000 \\
\hline \multirow{2}{*}{ Library collection and facilities } & Pearson $(r)$ & $.51 \mathrm{I}^{*}$ & $.524^{*}$ & $.558^{*}$ \\
\hline & Sig. (2-tailed) & .000 & .000 & .000 \\
\hline \multirow{2}{*}{ Computer/internet facilities } & Pearson $(r)$ & $.426^{*}$ & $.438^{*}$ & $.488^{*}$ \\
\hline & Sig. (2-tailed) & .000 & .000 & .000 \\
\hline \multirow{2}{*}{ Technical equipment } & Pearson $(r)$ & $.543^{*}$ & $.559^{*}$ & $.551^{*}$ \\
\hline & Sig. (2-tailed) & .000 & .000 & .000 \\
\hline \multirow{2}{*}{ Emphasis on research } & Pearson $(r)$ & $.532^{*}$ & $.537^{*}$ & $.557^{*}$ \\
\hline & Sig. (2-tailed) & .000 & .000 & .000 \\
\hline \multirow{2}{*}{$\begin{array}{l}\text { Participation in research } \\
\text { projects }\end{array}$} & Pearson $(r)$ & $.525^{*}$ & $.547^{*}$ & $.526^{*}$ \\
\hline & Sig. (2-tailed) & .000 & .000 & .000 \\
\hline \multirow{2}{*}{ Extra-curricular activities } & Pearson $(r)$ & $.552^{*}$ & $.528^{*}$ & $.596^{*}$ \\
\hline & Sig. (2-tailed) & .000 & .000 & .000 \\
\hline \multirow{2}{*}{$\begin{array}{l}\text { Opportunities for community } \\
\text { activities }\end{array}$} & Pearson $(r)$ & $.503^{*}$ & $.552^{*}$ & $.602^{*}$ \\
\hline & Sig. (2-tailed) & .000 & .000 & .000 \\
\hline
\end{tabular}




\begin{tabular}{lllll} 
Table Continued & & & \\
\hline & & Getting a job & \multicolumn{2}{c}{$\begin{array}{c}\text { Long-term career } \\
\text { prospects }\end{array}$} \\
\hline Availability of scholarships & Pearson $(\boldsymbol{r})$ & $.482^{*}$ & $.512^{*}$ \\
development & $.462^{*}$ \\
$\begin{array}{l}\text { Student participation in policy } \\
\text { formation }\end{array}$ & Sig. (2-tailed) & .000 & .000 & .000 \\
\hline $\begin{array}{l}\text { Provision of work-related } \\
\text { experiences }\end{array}$ & Sig. (2-tailed) & $.463^{*}$ & .000 & .000 \\
\hline
\end{tabular}

*significant at $\alpha=0.05$

\section{References}

1. Rindermann H. Relevance of education and intelligence for the political.. - Google Tudós. Intelligence. 2007;36(4):306-322.

2. Overtoom C. Employability skills: An update. ERIC Digest. 2010:4.

3. Gottfredson LS. Why g matters: The complexity of everyday life. Intelligence. 1997;24(1):79-132.

4. Hanushek EA, Kimko DD. Schooling, labor-force quality, and the growth of nations. Am Econ Rev. 2000;90(5):1184-1208.

5. Lynn R, Vanhanen T, Stuart M. IQ and the Wealth of Nations. Greenwood Publishing Group; 2002.

6. Barber N. Educational and ecological correlates of IQ: A cross-national investigation. Intelligence. 2005;33(3):273-284.

7. Ceci SJ. How much does schooling influence general intelligence and its cognitive components? A reassessment of the evidence. Dev Psychol. 1991;27(5):703.

8. Luria AR. Cognitive Development: Its Cultural and Social Foundations. Harvard university press; 1976.

9. Posner G. Analyzing the Curriculum. New York: McGraw-Hill; 2004.

10. Hiim H. Ensuring curriculum relevance in vocational education and training: Epistemological perspectives in a curriculum research project. Int J Res Vocat Educ Train. 2017;4(1):1-19.

11. Croy G, Eva N. Student success in teams: intervention, cohesion and performance. Educ Train. 2018;60(9):1041-1056.

12. Mayworm AM, Sharkey JD, Hunnicutt KL, Schiedel KC. Teacher consultation to enhance implementation of school-based restorative justice. J Educ Psychol Consult. 2016;26(4):385-412.

13. Manthra Prathoshni S, Vishnu Priya V, Gayathri R. Effect of teaching aids on student's academic performance in professional courses. Drug Invent Today. 2018;10(12).

14. Chan Y-K. Investigating the relationship among extracurricular activities, learning approach and academic outcomes: A case study. Act Learn High Educ. 2016;17(3):223-233.
15. Carolan BV. Extracurricular activities and achievement growth in kindergarten through first grade: The mediating role of non-cognitive skills. Early Child Res Q. 2018;45:131-142.

16. Rollason E, Bracken LJ, Hardy RJ, Large ARG. Evaluating the success of public participation in integrated catchment management. J Environ Manage. 2018;228:267-278.

17. Mathers CE, Finney SJ, Hathcoat JD. Student learning in higher education: a longitudinal analysis and faculty discussion. Assess Eval High Educ. 2018:1-17.

18. Ehren M, Perryman J. Accountability of school networks: Who is accountable to whom and for what? Educ Manag Adm Leadersh. 2018;46(6):942-959.

19. Print M. Can Resilience be built Through a Citizenship Education Curriculum? JSSE - J Soc Sci Educ. 2014;13(3). doi:10.2390/jssev13-i3-1342

20. Saxena A, Lawrence K, Desanghere L, et al. Challenges, success factors and pitfalls: implementation of distributed medical education. Med Educ. 2018;52(11):1167-1177.

21. Laguador JM, Chavez NH. ASSESSMENT OF ENGINEERING STUDENTS'ACQUIRED AFFECTIVE LEARNING FROM INVOLVEMENT IN COMMUNITY EXTENSION SERVICES. Acad Res Int. 2013;4(3):188.

22. Bennett S, Hoffmann T, Arkins M. A multi-professional evidencebased practice course improved allied health students' confidence and knowledge. J Eval Clin Pract. 2011;17(4):635-639.

23. Dimitrova R, Ferrer-Wreder L, Ahlen J. School Climate, Academic Achievement and Educational Aspirations in Roma Minority and Bulgarian Majority Adolescents. In: Child \& Youth Care Forum. Springer; 2018:1-14.

24. Bhorkar S, Bray M. The expansion and roles of private tutoring in India: From supplementation to supplantation. Int J Educ Dev. 2018;62:148-156. 